\title{
Disaster Chain Analysis of Avalanche and Landslide and the River Blocking Dam of the Yarlung Zangbo River in Milin County of Tibet on 17 and 29 October 2018
}

\author{
Huicong Jia ${ }^{1} \oplus$, Fang Chen ${ }^{1,2,3, *}$ and Donghua Pan ${ }^{4}$ \\ 1 Key Laboratory of Digital Earth Science, Institute of Remote Sensing and Digital Earth, Chinese Academy of \\ Sciences, Beijing 100094,China; jiahc@radi.ac.cn \\ 2 University of Chinese Academy of Sciences, Beijing 100049, China \\ 3 Hainan Key Laboratory of Earth Observation, Institute of Remote Sensing and Digital Earth, Chinese \\ Academy of Sciences, Sanya 572029, China \\ 4 Department of Integrated Disaster Risk Reduction, Ministry of Emergency Management of the People's \\ Republic of China, Beijing 100021, China; eliteast@mail.bnu.edu.cn \\ * Correspondence: chenfang_group@radi.ac.cn; Tel.: +86-10-8217-8105
}

Received: 15 October 2019; Accepted: 22 November 2019; Published: 26 November 2019

\begin{abstract}
As a "starting zone" and "amplifier" of global climate change, the Qinghai-Tibet Plateau is very responsive to climate change. The global temperature rise has led directly to an acceleration of glacial melting in the plateau and various glacier avalanche disasters have frequently occurred. The landslide caused by glacier avalanches will damage the surrounding environment, causing secondary disasters and a disaster chain effect. Take the disaster chain of the Yarlung Zangbo River at Milin County in Tibet on 17 and 29 October 2018 as an example; a formation mechanical model was proposed. The evolution mechanism for the chain of events is as follows: glacial melt $\rightarrow$ loose moraine deposit $\rightarrow$ migration along the steep erosion groove resulting in glacier clastic deposition then debris flow $\rightarrow$ formation of the dam plug to block the river $\rightarrow$ the dammed lake. This sequence of events is of great significance for understanding the developmental trends for future avalanches, landslides, and river blocking dam disasters, and for disaster prevention planning and mitigation in the Qinghai-Tibet Plateau.
\end{abstract}

Keywords: Yarlung Zangbo River; disaster chain; avalanche; landslide; river blocking dam; Qinghai-Tibet Plateau

\section{Introduction}

In recent years, due to the intensification of natural variability caused by global climate change, the global natural disaster activities have becoming more and more frequent and severe. Along with rapid population growth, the continuous development of the social economy and acceleration of urbanization, strengthened natural disasters have significant impacts on production, daily life, and socioeconomic development [1-3]. The chain rule makes this effect much more significant. So the disaster chain has become a hotspot in the disaster research field [4-7].

The concept of a disaster chain was first developed from the basic theory of disaster science, which was proposed by Chinese seismologist Guo Zengjian in 1987 [8]. The disaster chain was considered to be a series of disasters. Researchers have different understandings on the concept of disaster chains. Feng [9] believes that the disaster chain is a series of disasters caused by primary disasters and one or more secondary disasters within a complex disaster chain transmission relationship, which is affected 
by various environmental factors. $\mathrm{Ni}$ [10] defined the disaster chain as a continuous or synchronous disaster chain sequence, which consists of two or more disasters through causality, homology, and so on. Menoni [11] substituted the concept of chain of losses and failures to the simple couple of hazardous events-damages. In the journal Nature, from the perspective of disaster chain response, Helbing [12] pointed out that "there is usually a causal relationship between disasters, which makes the complexity of the disaster system deepen". Carpignano [13] stated that the domino phenomenon is caused by the stimulating effect between disaster events that constitute a disaster chain.

In order to prevent the occurrence of disasters and minimize the risk of disasters, it is necessary to understand the evolutionary laws of the occurrence, development, and transformation of disaster chains [14]. Shi et al. [15] realized the definition of disaster as a result of the comprehensive effect of the disaster-causing environment, the hazard factor, and the disaster-affected body from the perspective of geography, and he considered that the disaster chain is a complex disaster system. Xiao [16] and Liu [17] gave a definition of the disaster chain from the perspective of a mathematical level, and they further analyzed the relationship between the internal structural elements of the disaster chain. In terms of the transmission effect of disaster chain, Wen [18] proposed the concept of disaster chain transmission. Follow-up scholars further developed the concept of disaster formation ring, triggering ring, damage ring, and chain-breaking ring in the process of disaster chain transmission, which promoted the theoretical study of the chain characteristics of the disaster chain [19].

At present, the researches on disaster chains, a complex disaster system, are still at the early stage. Generally, the mathematical methods like statistical analysis are used to discuss the disaster chain from different aspects such as risk assessment, disaster loss estimation, and chain-cutting disaster mitigation. For example, through the establishment of a structural graph of a powerful earthquake disaster chain, the Bayesian networks (BNs) are used for the analysis of the key hazard factors affecting life safety in the process of earthquake disaster chain transmission [20]. In the risk assessment of disaster chain, some experts have established models based on complex networks for the risk assessment of typhoon disaster chain [21,22]. Asghar [23] proposed a conceptual model of disaster management. Cyganik [24] and Haddow [25] proposed a disaster chain management procedure from the stages of mitigation, preparedness, response, and recovery. However, the chain reaction processes were not considered. It is impossible to capture the evolution process of disasters to respond to the unknown disaster events in a timely manner. Therefore, the management of disasters would be delayed. May [26] proposed the concept of "cascading threat modeling" to establish a causal relationship model between disaster events. At present, the research on the disaster chain focuses on risk assessment and early warnings of the disaster chain. On the other hand, the existing literature has shortcomings in the semantic association and dynamic description of the evolution process of the disaster chain. Most of them simply simulate the evolution process of disasters from the perspective of visualization $[27,28]$, and they mainly focus on simple spatial and temporal phenomena [29]. Thus research on modeling the evolution process of disaster chains is still lacking.

The high mountain hazard chain is a catastrophic phenomenon of one mountain hazard triggering other mountain hazards under the action of inducing disaster factors. It often consists of two or more high mountain hazards such as debris flow, flash flood, landslide, collapse, ice avalanche, snow avalanche, and soil erosion [30-33]. The high mountain hazard chain is the result of mass transfer and energy conversion of mountain hazards [34]. Although there are some studies on mountain disaster chains, scholars have also explored some prevention and control methods, such as chain-cutting disaster mitigation from gestation source, and the prevention and control of disasters in the chain $[35,36]$.

Landslides and damming the Yarlung Zangbo River at Milin County in Tibet, are two typical cases that occurred on 17 and 29 October 2018. In the Sedongpu Basin, two landslides blocked the river within 13 days, and the river burst its banks after two days (Figure 1). The dammed lake constitutes a water body with a certain amount of solid matter blocked by mountain river valleys or rivers. In general, a dammed lake refers to a naturally formed water body. These dammed lakes are widely distributed throughout the world, especially in mountain valleys where earthquakes occur 
frequently [37]. There are many barrier lakes at different scales in China's mountainous areas, and breaches from some of these dammed lakes have resulted in serious environmental disturbances. China's barrier lakes are mainly distributed in alpine valleys and alpine regions, and some large earthquakes have resulted in the failure of these barrier lakes [38-41]. In particular, high mountain and canyon areas with steep and rugged terrain, which experience new tectonic movements, including earthquakes, are active, such that landslides and mudslides have become more frequent [42]. Once large-scale landslides and mudslides occur, blockage of the main river and formation of a barrier lake occurs. Frigid and high-altitude areas tend to be the areas where modern glaciers and glacial lakes develop, and many moraine-dam lakes are known. Between 1949 and 1994, there were 78 incidents of landslides which blocked rivers in mainland China, mainly in the southwestern mountains of Sichuan, Yunnan, and Tibet. There was also a small number of such occurrences in Hubei, Guizhou, Hunan, Shaanxi, Gansu, Qinghai, and Xinjiang [43-45]. In 2008, the Wenchuan earthquake gave rise to the formation of 256 barrier lakes, which were mainly distributed along the main rupture zone of the earthquake and $85.6 \%$ of the dammed lakes were distributed in the three major fault zones of Longmenshan and within $10 \mathrm{~km}$ of the fault [46].

The objective of this study is two-fold: (1) to analyze the "avalanche-landslide-debris flow-barrier lake" hazard mechanism and derivative disasters chain based on disaster system theory, and (2) to summarize the evolution process of the disaster chain and the organizing framework of chain-cutting disaster mitigation. These contributions may provide new insights into the disaster chain prevention and mitigation in the Qinghai-Tibet Plateau and other high mountain environments.

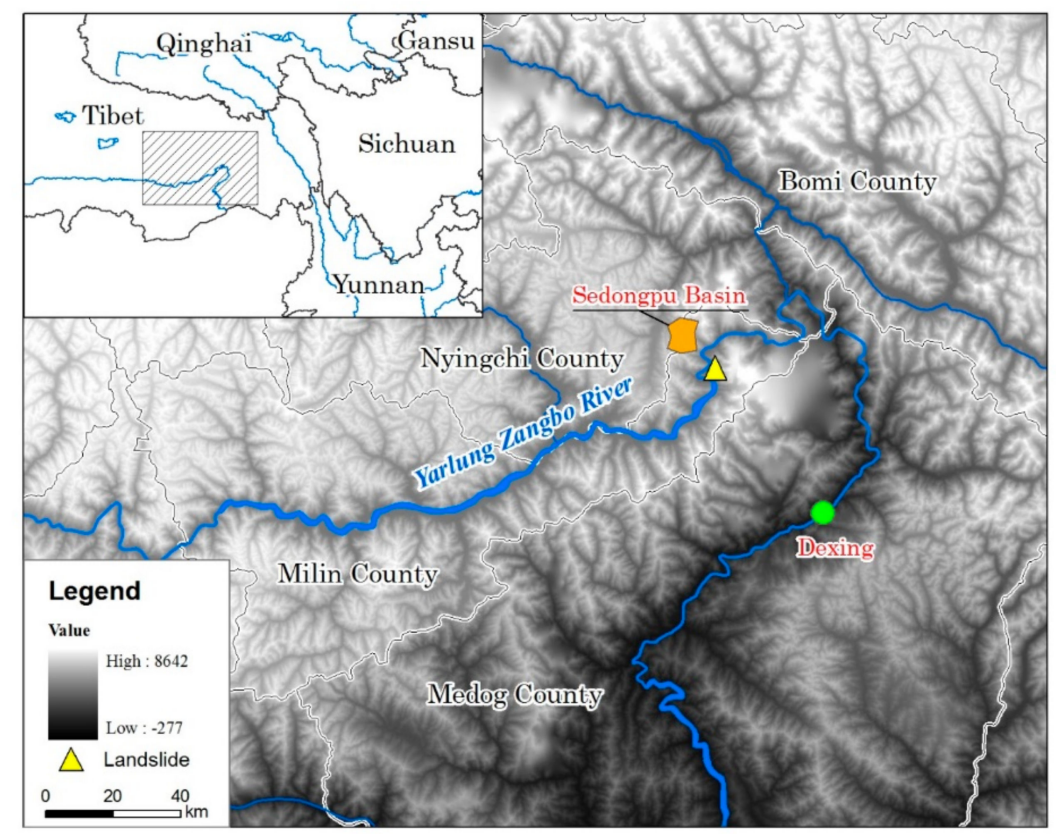

Figure 1. Location of the study area.

\section{Analysis of the Disaster Chain Process}

\subsection{Study Area and Data}

As a "starting zone" and an "amplifier" of global climate change, the Qinghai-Tibet Plateau is very responsive to climate change [47]. The district is characterized by its complex geology, high in-situ stresses, and earthquakes, repeating ground freeze and thaw, intensive precipitation, frequent landslides, and chained disasters [36-38,43-45]. The global temperature rise leads directly to an acceleration of glacial melting in the plateau and frequent occurrence of glacier avalanche disasters. Since 1961, the annual average temperature of the Qinghai-Tibet Plateau has increased significantly, with an average increase of $0.36{ }^{\circ} \mathrm{C}$ per 10 years [48]. The warming rate at the Tibetan Plateau is twice 
the rate of global warming. The Tibetan Plateau's climate and environment have undergone significant changes and the consequences of these changes are evident. The dry and wet seasons of the plateau are distinct, with the rainy season being from May to October (wet season) and the dry season from January to April. The plateau has become "wet", with an increase in precipitation of $4.5 \mathrm{~mm}$ per 10 years in the rainy season and $1.8 \mathrm{~mm}$ per 10 years in the dry season [49]. Analysis of remote sensing monitoring data shows that the overall area of the Purog Kangri Glacier has been reduced significantly over the period 1973 to 2016. In 2016, the area of the Purog Kangri Glacier was $389.0 \mathrm{~km}^{2}$, a decrease of $17.9 \%$ compared with 1973 [50]. The glacier change has been largest in the north, followed by the southeast, with the smallest change being in the west.

The thickness of the active layer in the permafrost regions in the Qinghai-Tibet Plateau has increased with the frozen soil degrading significantly. From 1981 to 2016, the thickness of the active layer increased significantly, with an average thickness of $18.9 \mathrm{~cm}$ per 10 years [51]. Since 1961, the maximum depth of frozen soil with an altitude above $4500 \mathrm{~m}$ has been the most obvious sign, with an average decrease of $15.1 \mathrm{~cm}$ per 10 years. The comparable thickness of the medium-altitude area, an altitude of 3200 to $4500 \mathrm{~m}$, was $4.6 \mathrm{~cm}$ per 10 years; and for altitudes below $3200 \mathrm{~m}$ the decrease in thickness was even less. In 2016, the maximum depth of frozen soil in the high-altitude areas was the lowest since 1961, which was $91 \mathrm{~cm}$ less than the average annual value [52].

The Yarlung Zangbo River is an international river and discharge of the barrier lake will affect downstream regions in India. Inappropriate management of the river may lead to international disputes. Moreover, disaster emergency control measures may be severe, population control, transfer and resettlement are usually challenging, and the rise and fall of the dam water would likely cause secondary disasters, which would seriously threaten the upstream and downstream residential areas and major infrastructure.

The analyzed data were retrieved from the digital elevation model (DEM) data of the study area with $30 \mathrm{~m}$ resolution (ASTER GDEM data from the National Aeronautics and Space Administration, USA), the China Province Administrative vector map, the earthquake distribution map (China Earthquake Administration), daily precipitation data download from the China Meteorological Data Sharing Service System (http://cdc.cma.gov.cn/) of Milin County for 1979-2018, and the remote sensing data provided by the Ministry of Natural Resources of China and Ministry of Emergency Management of China.

\subsection{Disaster Body Formation Process}

Early in the morning of 17 October 2018, a landslide occurred in Jiala village, Pai Town, Milin County, Nyingchi City, Tibet. A dam lake was formed in the Yarlung Zangbo River. The water level of the barrier lake rose rapidly at a rate of 0.8 to $1 \mathrm{~m} / \mathrm{h}$. Using three-dimensional (3D) remote sensing analysis along the river, the landslide dam was noted to be about $3500 \mathrm{~m}$ in length, $415-890 \mathrm{~m}$ wide, 77-106 $\mathrm{m}$ high, and a volume of the soil and dirt blocking the river was 30 million $\mathrm{m}^{3}$ [53,54]. The maximum water depth of the barrier lake was $77 \mathrm{~m}$ and the water storage capacity was about 320 million $\mathrm{m}^{3}[55,56]$.

The maximum elevation of the debris flow formation zone was about $4100 \mathrm{~m}$, the debris flow circulation zone was about $8.3 \mathrm{~km}$ long, and the average gradient ratio was about $21 \%$. The basic composition of the sediment deposit material was gravel and gravel soil, and the top elevation was 2830-2860 m. The bottom elevation was about $2750 \mathrm{~m}$, the flow direction was about $2.4 \mathrm{~km}$ long, the width was about $850 \mathrm{~m}$, and the estimated volume was about 40 to 60 million $\mathrm{m}^{3}$. The maximum water depth before the dam was about $79.43 \mathrm{~m}$, the return water length was $26.0 \mathrm{~km}$, the natural channel ratio in the backwater area was about $3.05 \%$, and the natural drop in the backwater area was about $79.3 \mathrm{~m}$. The return water level was $2840 \mathrm{~m}$, and the estimated storage capacity was 605 million $\mathrm{m}^{3}$. The damming water body began to naturally overflow at 13:30 on 19 October, and the flow rate gradually increased. The estimated maximum instantaneous flow rate was $32,000 \mathrm{~m}^{3} / \mathrm{s}$. At 21:30 on 19 October, the flood reached the Dexing Hydrological Station in Medog County (168 km downstream 
of the dam body). At 23:40 on 19 October, the peak water level appeared. The maximum water level increased by $19.76 \mathrm{~m}$, and the corresponding flow rate was $23,400 \mathrm{~m}^{3} / \mathrm{s}$. By 16:00 on 20 October, the flow rate was $3030 \mathrm{~m}^{3} / \mathrm{s}$. The water storage capacity of the dammed lake which passed through the Dexing station section was 580 million $\mathrm{m}^{3}$, the water level of the dammed lake had dropped by $72 \mathrm{~m}$, and the amount of water entering and leaving the lake had reached equilibrium (Figure 2).

In the early morning of 29 October, the Yarlung Zangbo River dammed lake from 17 October formed a glacial debris flow due to the melting of ice debris and other ice bodies, which caused the Yarlung Zangbo River to stop flowing and form a dammed lake again. Using 3D remote sensing measurement data analysis, the dam body was about $3500 \mathrm{~m}$ long, 415-890 m wide, 77-106 $\mathrm{m}$ high, and the total volume was about 30 million $\mathrm{m}^{3}$. At 9:30 on 31 October, the landslide dam naturally overflowed, and the maximum overflow of the landslide dam was estimated to be about $18,000 \mathrm{~m}^{3} / \mathrm{s}$ at 12:30. At 18:30, the flood passed downstream through Medog County, and then the water level turned back. At 9:00 on 1 November, the water level downstream in Medog County fell and returned to normal. At 18:30, the peak flow passed Medog County, and then the water level started to fall back. At 9:00 on 1 November, the water level in Medog County returned to normal levels.

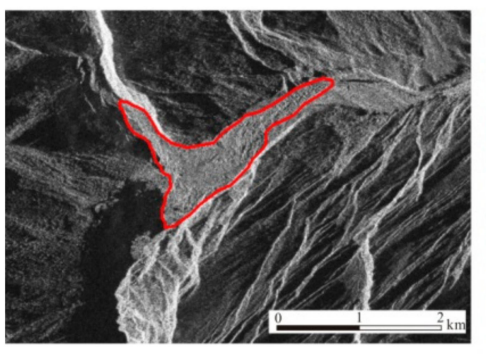

(a) 18 October 2018

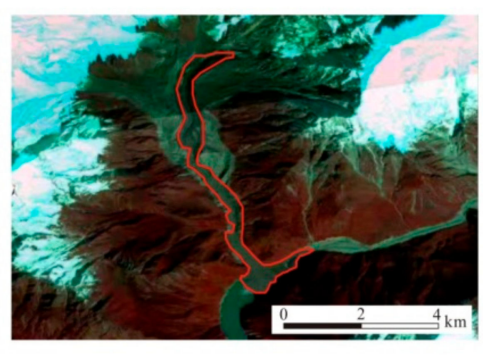

(b) 30 October 2018

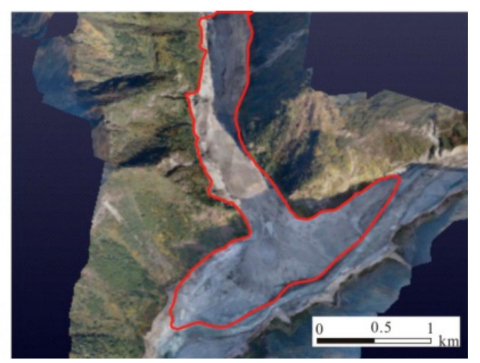

(c) 1 November 2018

Figure 2. Comparison of remote sensing images before and after the collapse of the barrier lake.

\section{Analysis of the Causes of the Disaster Chain of Events}

\subsection{Analysis of the Hazard Factors Affecting the Disaster Chain}

The Yarlung Zangbo River barrier lake was caused by landslides and mudslides blocking the river. The dammed lakes occurred in an alpine valley area where the terrain is steep. The height difference in the terrain is higher than $1000 \mathrm{~m}$ and the potential energy is very large (Figure 3). It is relatively easy for a high-level landslide to occur in this region. The landslide can slide for several $\mathrm{km}$ or even $10 \mathrm{~km}$, forming a dammed lake in the river.

The water storage capacity of the two barrier lakes reached 100 million $\mathrm{m}^{3}$ in just several to tens of hours, and the growth rate was rapid, mainly due to the large river flow in the area where the lake was affected. According to the precipitation data of the meteorological department, the recent precipitation in the southeastern part of the Qinghai-Tibet Plateau was significantly higher than that in the same period of the previous year, and in some areas it was four times greater. From May to October 2018, the precipitation at Milin was $422.9 \mathrm{~mm}$, which was $28.7 \%$ less than that for a typical year $(593.1 \mathrm{~mm})$. Since May, the precipitation in May-August and October was less than $100 \mathrm{~mm}$; among these months, the precipitation in June, July, and August was $40-50 \%$ less than normal. However, in September, more precipitation occurred, in excess of $50 \%$ of normal levels (Figure 4 ). 


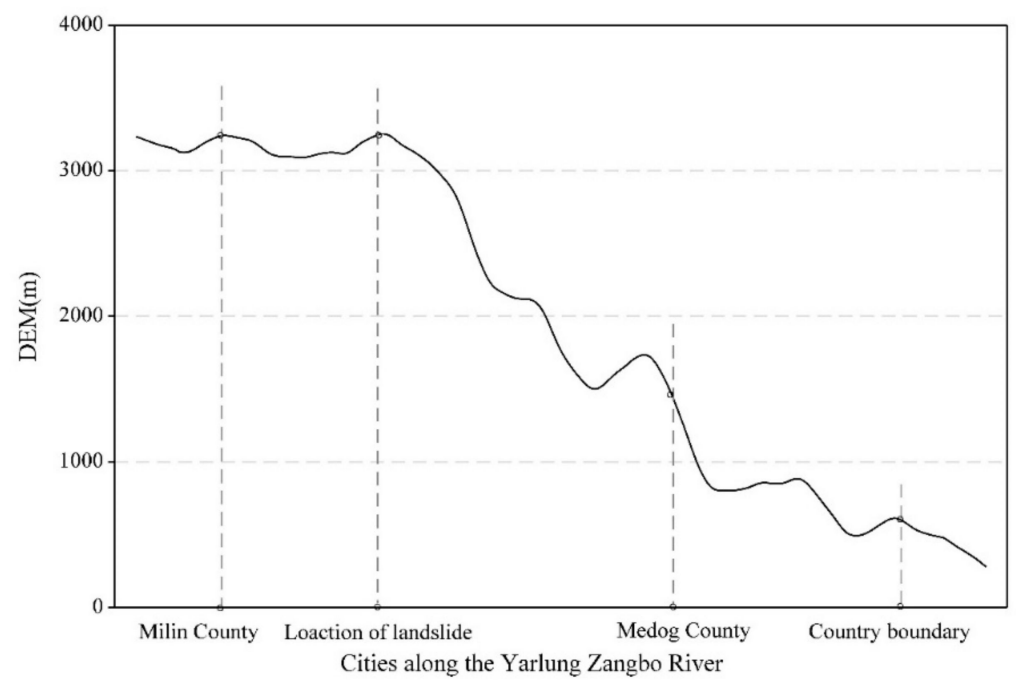

Figure 3. Digital elevation model (DEM) of the study area.

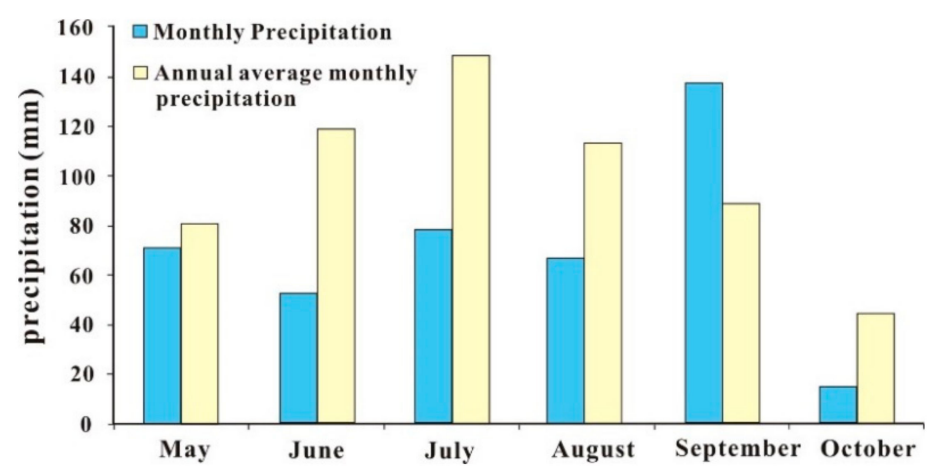

Figure 4. Monthly precipitation in Milin County from May to October 2018.

From geological considerations, the barrier lakes are located on the eastern edge of the Qinghai-Tibet Plateau where earthquake activity is strong. On 22 August 2013, a magnitude 6.1 earthquake occurred at the junction of Zuogong County and Mangkang County in Changdu City. On 18 November 2017, a magnitude 6.9 earthquake occurred in Milin County, Nyingchi City. The Milin earthquake triggered the bottom of the Gyala Peri glacier in the northern part of the Yarlung Zangbo River to become mobile and active, and movement sped up [57,58]. Coupled with recent climate change, the melting of glaciers or ice lakes resulted in a huge amount of sediment being deposited in the barrier lake. Given the geological structure, topography, and climate of the region, local natural weathering is a serious factor and landslides often occur.

There have been 22 earthquakes of magnitude 3 or higher since 2012 in the vicinity of the Sedongpu Basin (Figure 5). On 18 November 2017, the epicenter of the Milin 6.9 earthquake was about $10 \mathrm{~km}$ away from the mouth of the Sedongpu Basin and the focal depth was $8 \mathrm{~km}$ [59]. This earthquake to some extent destroyed the stability of the glacier structure, the accumulations in the valleys, and the moraine. 


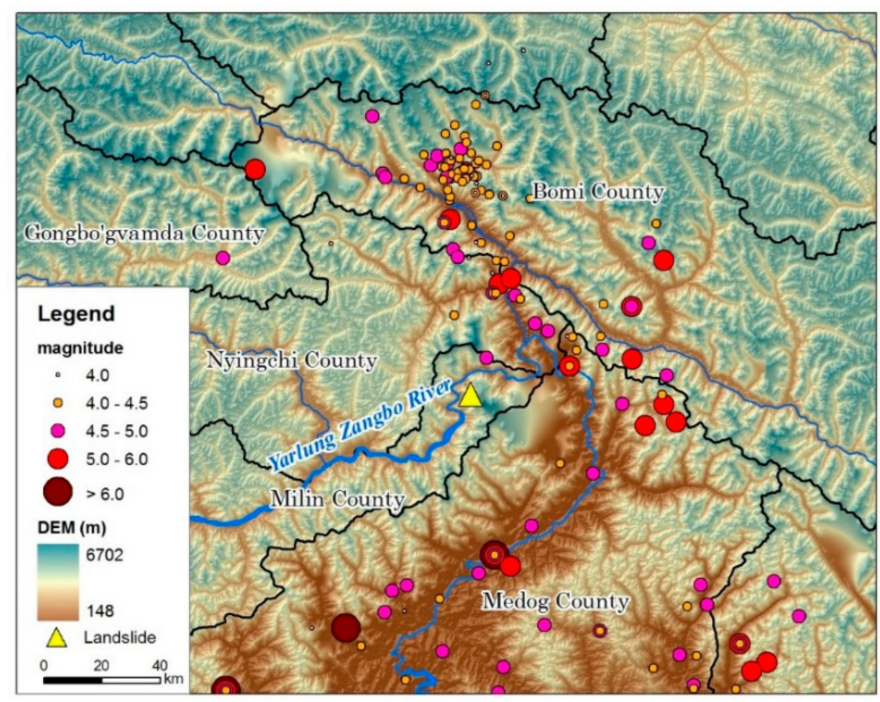

Figure 5. Recent earthquake distribution map for the study area (1949-2018).

There are many ice crevasses in the middle of the glaciers and the ends of the glaciers are covered by moraine. The glaciers over the entire valley melted considerably. In 1970, the glaciers of the Sedongpu Basin were an integrated whole. At present, the glaciers are divided into many branches due to strong ablation. The Sedongpu Basin is about $2100 \mathrm{~m}$ long and $115 \mathrm{~m}$ wide [45]. According to a comparative analysis of remote sensing images for 26, 27, and 30 October 2017 glacial meltwater was the main cause of this debris flow (Figure 6).
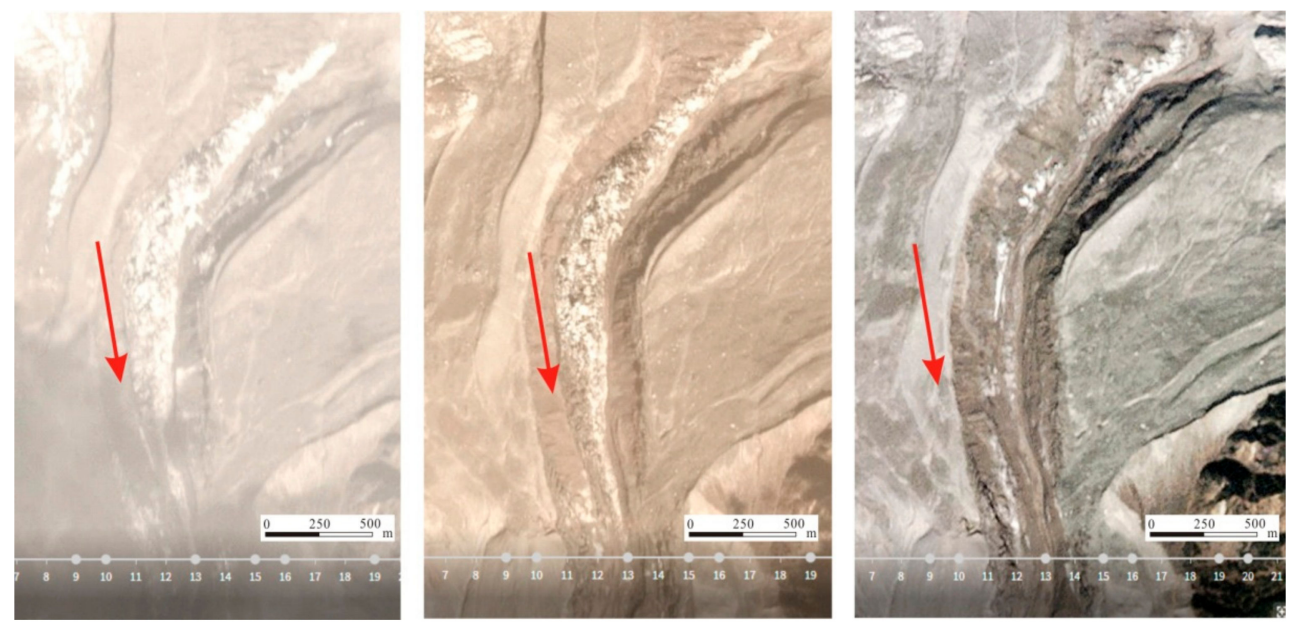

Figure 6. Comparison of remote sensing imagery on 26, 27, and 30 October 2017 for avalanche deposits in the Sedongpu Basin.

\subsection{Long-Term Accumulation of Rock Debris}

As early as 2015, satellite imagery showed that the surface of the slope near the Jinshajiang River landslide point was deformed and broken, and the rock mass slippage was clear. The median value of the average displacement of the landslides was $5.4 \mathrm{~m}$ from March to May 2018, $9.3 \mathrm{~m}$ from May to July, and $11.8 \mathrm{~m}$ from July to September. The top of the Yarlung Zangbo River landslide dam had a large landslide from 5 January 2016 to 8 June 2018 [37,40]. The snow-covered sediment was transported to the Yarlung Zangbo River, partially deposited in the middle of the mountain. Since the lower mountain pass was narrow, it resulted in a continuous pressure on the lower mountain sides. By September 2018, the mountain was deformed, and although the Yarlung Zangbo River did not break through, the river surface was severely blocked, eventually leading to the formation of a dammed lake (Figure 7). 

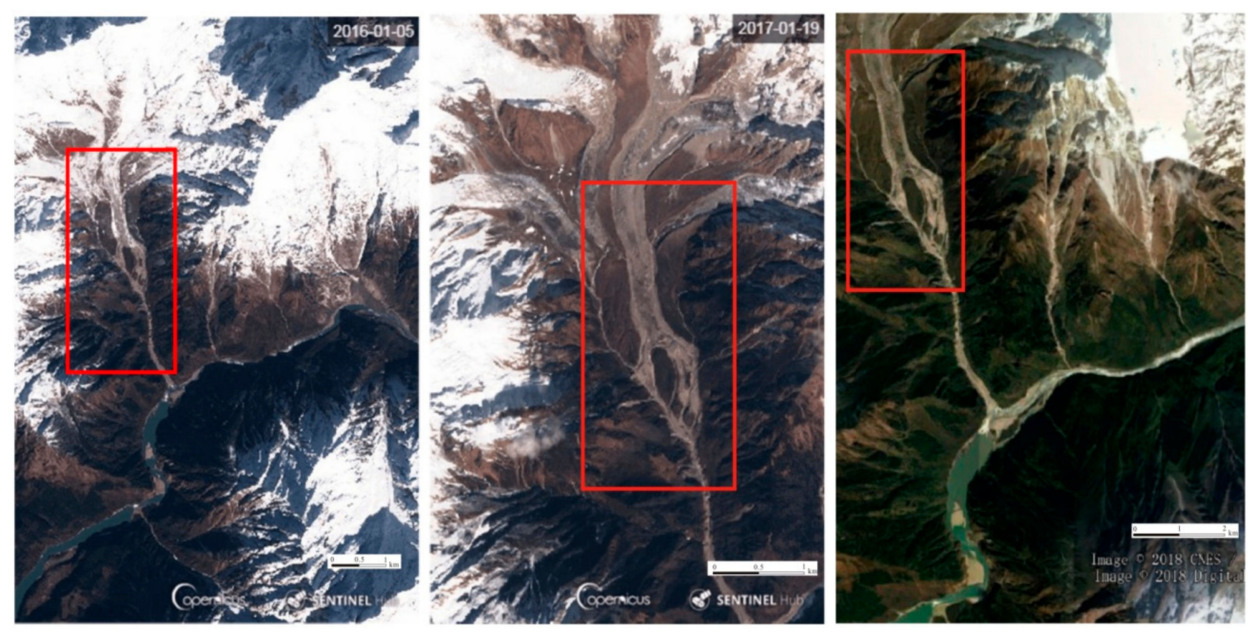

Figure 7. Changes in gully and sediment in the upper margin of the Yarlung Zangbo River (2016-2018).

\section{Discussion}

The avalanche and landslide and the river blocking dam disaster chain can be defined as: one or more geological hazards (such as a series of successive events in time, spatially dependent, interrelated, causal, and causing a chain reaction in sequence) that occur in succession [58-60]. This results in effectively a chain of disasters that block rivers due to avalanches, landslides, mudslides, and debris flow (Figure 8).

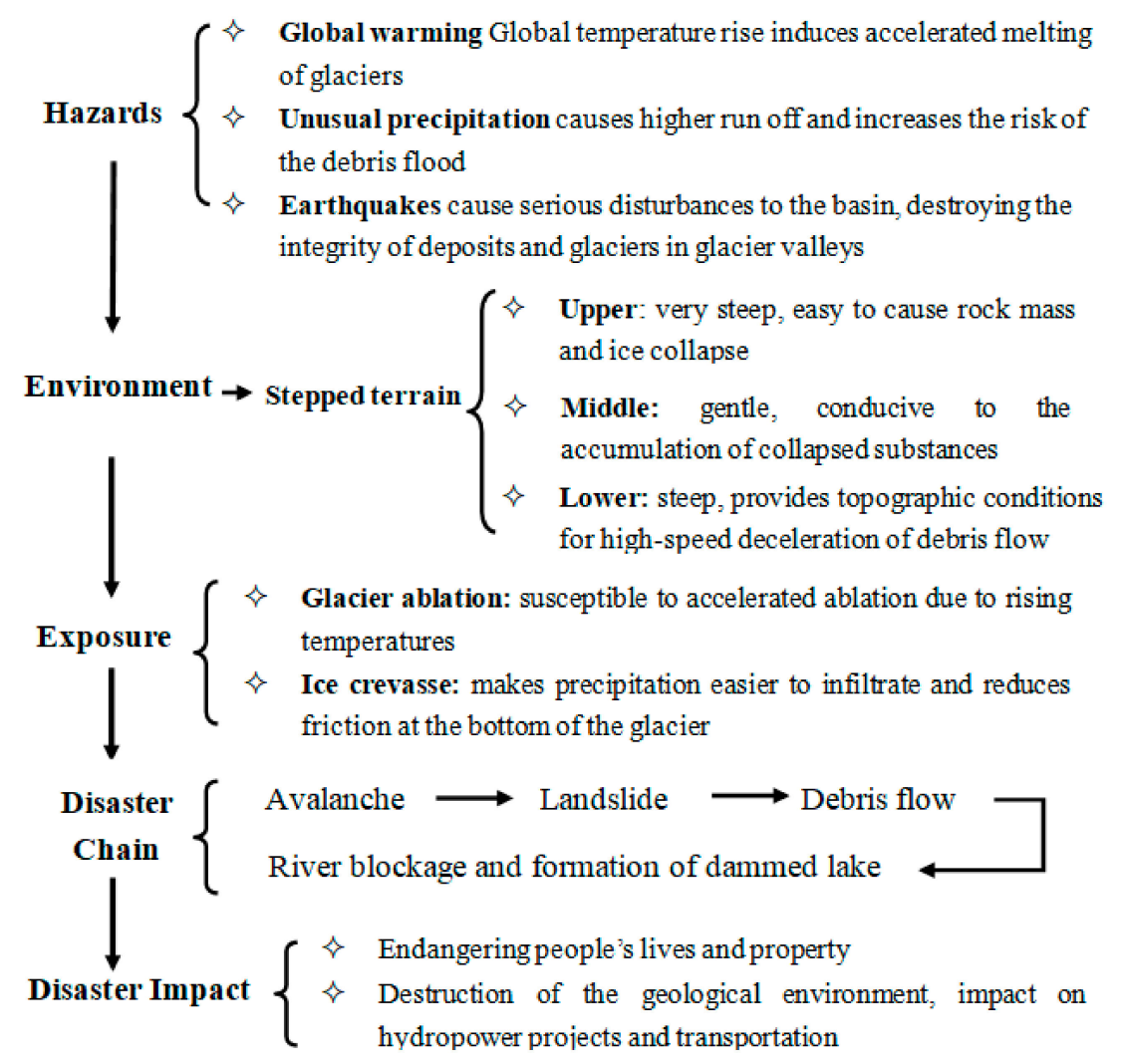

Figure 8. The evolution mechanism of the disaster chain (avalanche-landslide-debris flow-barrier lake).

Landslides and the collapse of dams as a result of a series of earthquakes often occur in the form of a disaster chain. Generally, there are disaster chain models that are caused by single disasters and disaster chain models arising as a result of the coupling of multiple disasters. A kind of landslide and 
collapse disaster may be accompanied by other landslide and collapse disasters; or after the first kind of landslide disaster, another new kind of landslide disaster may be induced, that is, the first kind of landslide disaster reverted from the initial "damage ring" to the later "hazard inducing ring" [36-38].

The mechanistic path of the disaster chain may be represented as follows: glacial meltwater $\rightarrow$ mobilization of loose moraine $\rightarrow$ migration along the steep slope of the erosion trough to form glacier debris flow $\rightarrow$ formation of the dam plug to block the river channel $\rightarrow$ the dammed lake.

The long-term monitoring of the Sedongpu Basin and possible areas affected by formation of barrier lakes in the Yarlung Zangbo River should be strengthened. There are many loose deposits in the Sedongpu Basin, which have led to the blockage of the Yarlung Zangbo River many times throughout history. It is recommended that the Tibet Autonomous Region and relevant departments use high-resolution satellites, such as InSAR (Interferometric Synthetic Aperture Radar), for long-term monitoring of glaciers and gullies in the Sedongpu Basin [29,30]. Possible river blocking and risk assessment should be undertaken. It is also recommended that there should be construction of a high-standard automatic water level monitoring station in the vicinity of the upper reaches of the damming body for hydrological emergency monitoring and early warning work [40,41].

There should be further expansion of the geological and glacier surveys of the river section near the dammed body. In the ravine near the dammed body, there were also signs of glacial debris flow $[44,45]$. Based on a previous investigation, detailed geological disaster planning should be implemented, and specific relocation, monitoring or engineering treatment plans should be drawn up for potential major hazards.

An emergency response decision support platform for barrier lakes should be formulated such that there is a sharing of basic information on relevant land, hydrology, meteorology, earthquake, and other relevant factors [38]. Also a rapid risk assessment of the barrier lake including rapid analysis of the reservoir, upstream incoming water prediction, upstream flooding, damming object characteristics and stability, dam flood and downstream impact should be realized. In addition, a remote network consultation facility should be established to provide decision support for emergency response planning and implementation.

\section{Conclusions}

The warming rate of the Qinghai-Tibet Plateau is twice the rate for the global average. Against a background of rapid global warming, the instability of glaciers will increase, ablation will increase, and avalanche disasters will continue or even become more frequent; especially secondary disasters which will lead to the formation of disaster chains with the following features:

(1) There is a significant amplification effect in the avalanche chain.

The disaster chain will cause the disaster-affected body to suffer continuous damage in a short period of time. The lack of a holistic and systematic disaster prevention and mitigation system would not be able to cope with the situation of multi-disasters where the various functions in the disaster system are interrelated and form a strong net effect. The net effect will make the crisis spread rapidly, making the "amplification" of the effect of the disaster more apparent.

(2) The avalanche chain often shows a long chain effect.

A disaster chain with more than three "chain" sections is often referred to as a long chain. The most prominent feature of the long chain is that even if the front chain dies out, the rear chain is still likely to continue, and the disaster is difficult to stop. There are many reasons why a long chain of avalanches and landslides occur resulting in a river blocking dam disaster chain. The main reason is that there are many disaster sources, and natural disasters readily overlap with human disasters, resulting in amplification of the disaster.

(3) The avalanche chain can show a shrinkage effect. 
If the disaster crisis is managed inappropriately, there will be an amplification of the disaster chain; if properly managed, however, there can be some control of the avalanche and landslide and the river blocking dam, so that the disaster chain will not continue, and thus the effect of the broken chain can be effectively reduced. Therefore, as a future research goal, it is imperative that we understand the mechanisms and processes of the avalanche, the landslide and the river blocking dam disaster chain, so that a comprehensive assessment of risk can be achieved in such a way that there is a rational allocation of disaster prevention and mitigation resources to ensure that the impact of avalanches and landslides is minimized.

Author Contributions: Conceptualization, D.P. and H.J.; formal analysis, H.J.; data and resources, F.C.; writing —original draft preparation, H.J.; writing—review and editing, F.C.; supervision, F.C. and H.J.; funding acquisition, F.C. and H.J.

Funding: This work was supported by the National Key R\&D Program of China (2017YFE0100800), the International Partnership Program of the Chinese Academy of Sciences (131211KYSB20170046; 131551KYSB20160002), the National Natural Science Foundation of China (41671505; 41471428; 41871345), the State Key Laboratory of Earth Surface Processes and Resource Ecology, Beijing Normal University (2017-KF-24).

Acknowledgments: The authors would also like to thank the editors and the three anonymous reviewers for their constructive comments and advice.

Conflicts of Interest: The authors declare no conflicts of interest.

\section{References}

1. Gill, J.C.; Malamud, B.D. Reviewing and visualizing the interactions of natural hazards. Rev. Geophys. 2014, 52, 680-722. [CrossRef]

2. Managing Disaster Risks and Water under Climate Change in Central Asia and Caucasus. Available online: https://reliefweb.int/sites/reliefweb.int/files/resources/managing_disaster_risks_and_water_under_ climate_change_in_ca_and_caucasus-compilation.pdf (accessed on 14 October 2019).

3. Gariano, S.L.; Guzzetti, F. Landslides in a Changing Climate. Earth Sci. Rev. 2016, 162, 227-252. [CrossRef]

4. Managing the Risks of Extreme Events and Disasters to Advance Climate Change Adaptation. Special Report of the Intergovernmental Panel on Climate Change. Available online: https:/www.ipcc.ch/site/assets/ uploads/2018/03/SREX_Full_Report-1.pdf (accessed on 14 October 2019).

5. Xu, L.; Meng, X.; Xu, X. Natural hazard chain research in China: A review. Nat. Hazards 2014, 70, 1631-1659. [CrossRef]

6. Wang, R.; Lian, F.; Yu, H.; Shi, P.J.; Wang, J.A. Classification and regional features analysis of global typhoon disaster chains based on hazard-formative environment. Geogr. Res. 2016, 35, 836-850.

7. Shi, P.J.; Shuai, J.B.; Chen, W.F.; Lu, L.L. Study on large-scale disaster risk assessment and risk transfer models. Int. J. Disaster Risk Sci. 2010, 1, 1-8.

8. Guo, Z.J.; Qin, B.Y. Brief discussion on disaster physics. J. Catastrophol. 1987, 2, 25-33.

9. Feng, Y. The status of floods and droughts in disasters. Beijing Water 1995, 5, 9-12.

10. Ni, H.Y.; Wang, D.W.; Bai, Y.J.; Liu, X.X. Structure Type and Countermeasures of Geo-hazard Chain Effects in Sunshui River Drainage, Sichuan, China. Mt. Res. 2016, 34, 451-459.

11. Menoni, S. Chains of damages and failures in a metropolitan environment: Some observations on the Kobe earthquake in 1995. J. Hazard. Mater. 2001, 86, 101-119. [CrossRef]

12. Helbing, D. Globally networked risks and how to respond. Nature 2013, 497, 51-59. [CrossRef]

13. Carpignano, A.; Golia, E.; Di Mauro, C.; Bouchon, S. A methodological approach for the definition of multi-risk maps at regional level: First application. J. Risk Res. 2009, 12, 513-534. [CrossRef]

14. Shi, P.J. Theory and practice on disaster system research in a fourth time. J. Nat. Disasters 2005, 14, 1-7.

15. Shi, P.J. Establishing national integrated disaster reduction strategy and improving catastrophe risk governance capacity. J. Nat. Disasters 2008, 17, 1-8.

16. Xiao, S.X. Originality structure sketch on chain-styled theory of disaster in eco-environment. Chin. J. Rock Mech. Eng. 2006, 25, 2594-2602.

17. Liu, W.F.; Xiao, S.X.; Sui, Y.C.; Zhou, J.F.; Gao, H.W. Analysis of natural disaster chain and chain-cutting disaster mitigation mode. Chin. J. Rock Mech. Eng. 2006, 25, 2675-2681.

18. Wen, C.J. Generalized disaster, disaster chain and their prevention and control. J. Catastrophol. 2000, 15, 13-18. 
19. Liu, A.H.; Wu, C. Research on risk assessment method of disaster chain based on complex network. Syst. Eng. Theory Pract. 2015, 35, 466-472.

20. Peters, K.; Buzna, L.; Helbing, D. Modelling of cascading effects and efficient response to disaster spreading in complex networks. Int. J. Crit. Infrastruct. 2008, 4, 46-62. [CrossRef]

21. Martha, J.; Subbakrishna, S. Targeting a just-in-case supply chain for the inevitable next disaster. Supply Chain Manag. Rev. 2002, 6, 18-23.

22. Wang, J.X.; Gu, X.Y.; Huang, T.R. Using Bayesian networks in analyzing powerful earthquake disaster chains. Nat. Hazards 2013, 68, 509-527. [CrossRef]

23. Asghar, S.; Alahakoon, D.; Churilov, L. A comprehensive conceptual model for disaster management. J. Humanit. Assist. 2006, 1360, 1-15.

24. Cyganik, K.A. Disaster preparedness in Virginia hospital center-Arlington after Sept 11, 2001. Disaster Manag. Response 2003, 1, 80-86. [CrossRef]

25. Haddow, G.; Bullock, J.; Coppola, D.P. Introduction to Emergency Management; Butterworth-Heinemann: Oxford, UK, 2017.

26. May, F. Cascading Disaster Models in Postburn Flash Flood. In The Fire Environment_Innovations, Management, and Policy; Butler, B.W., Cook, W., Eds.; U.S. Department of Agriculture, Forest Service, Rocky Mountain Research Station: Fort Collins, CO, USA, 2007; pp. 443-464.

27. Cui, Y.; Kong, J.M.; Tian, S.J. The critical role for heavy rainfall in the evolution of the mountain hazards chains. J. Mt. Sci. 2011, 29, 87-94.

28. Xu, M.Z.; Wang, Z.Y.; Qi, L.J. Disaster chains initiated by the Wenchuan earthquake. J. Mt. Sci. 2012, 30, 502-512. [CrossRef]

29. Zhu, J.; Yin, L.Z.; Cao, Z.Y.; Zhang, X.; Xu, Z.; Gong, J. Network Simulation and Visual Analysis of Spatiotemporal Process: A Case Study of Dam-break Flood Routing. J. Geo Inf. Sci. 2015, 17, $215-221$.

30. Li, W.X.; Wang, Z.Y.; Wang, X.Z.; Qi, L.J.; He, X.Y. Secondary Mountain Disaster Chain Induced by the Wenchuan Earthquake and the Result of Chain-cutting Engineering in the Xiaogangjian Gully. J. Mt. Sci. 2014, 32, 336-344.

31. Clague, J.; Evans, S. A review of catastrophic drainage of moraine-dammed lakes in British Columbia. Quat. Sci. Rev. 2000, 19, 1763-1783. [CrossRef]

32. Yu, H.; Wang, J.A.; Chen, M.; Shi, P.J. Review on research methods of disaster loss accumulation and amplification of disaster chains. Prog. Geogr. 2014, 33, 1498-1511.

33. Shi, P.J.; Lu, L.L.; Wang, M.; Wang, J.A.; Chen, W.F. Disaster system: Disaster cluster, disaster chain and disaster compound. J. Nat. Disasters 2014, 23, 1-12.

34. Li, M.; Tang, H.M.; Ye, S.Q. Research on Chain rule of typical geological disaster. J. Catastrophol. 2008, 23, 1-5.

35. Keefer, D.K. Investigating landslides caused by earthquakes-A historical review. Surv. Geophys. 2002, 23, 473-510. [CrossRef]

36. Meng, J.J.; Yang, Q. Research advances of chain-cutting disaster mitigation from gestation source in China. J. Saf. Environ. 2012, 12, 246-251.

37. Tong, L.Q.; Tu, J.N.; Pei, L.X.; Guo, Z.C.; Zheng, X.W.; Fan, J.H.; Zhong, C.; Liu, C.L.; Wang, S.S.; He, P.; et al. Preliminary discussion of the frequently debris flow events in Sedongpu Basin at Gyalaperi peak, Yarlung Zangbo River. J. Eng. Geol. 2018, 26, 1552-1561.

38. Wang, C.Z.; Yao, L.K.; Huang, Y.D.; Sarfraz, A. Railway Alignment Design Mitigation Strategies in High Risk Area of Landslide and Collapse Damming with the Chain of Quake Lake Disasters. Railw. Stand. Des. 2019, 63, 1-7.

39. Xu, Q.; Zheng, G.; Li, W.L.; He, C.Y.; Dong, X.J.; Guo, C.; Feng, W.K. Study on successive landslide damming events of Jinsha River in Baige Village on October 11 and November 3, 2018. J. Eng. Geol. 2018, 26, 1534-1551.

40. Xia, J.S.; Dong, P.L. Spatial characteristics of physical environments for human settlements in Jinsha River watershed (Yunnan section), China. Geomat. Nat. Hazards Risk 2019, 10, 544-561. [CrossRef]

41. Peng, D.L.; Xu, Q.; Dong, X.J.; Qi, X.; Ju, Y.Z.; Li, H.J. Accurate and efficient method for loess landslide fine mapping with high resolution close-range photogrammetry. J. Eng. Geol. 2017, 25, 424-435.

42. Chai, H.J.; Liu, H.C.; Zhang, Z.Y. The catalog of Chinese landslide dam events. J. Geol. Hazards Environ. Preserv. 1995, 6, 1-9.

43. Chai, H.J.; Liu, H.C.; Zhang, Z.Y. The temporal—Spatial distribution of damming landslides in China. J. Mt. Sci. 2000, 18, 51-54. 
44. Li, D.; Lu, X.; Yang, X.; Chen, L.; Lin, L. Sediment load responses to climate variation and cascade reservoirs in the Yangtze River: A case study of the Jinsha River. Geomorphology 2018, 322, 41-52. [CrossRef]

45. Hu, W.T.; Yao, T.D.; Yu, W.S.; Yang, W.; Gao, Y. Advances in the study of glacier avalanches in High Asia. J. Glaciol. Geocryol. 2018, 40, 1141-1152.

46. Yang, W.T.; Wang, M.; Shi, P.J.; Shen, L.L.; Liu, L.Y. Object-oriented rapid identification of landslides based on terrain factors segmentation and classification. J. Nat. Disasters 2015, 24, 1-6.

47. Shangguan, D.H.; Liu, S.Y.; Ding, Y.J.; Guo, W.Q.; Xu, B.Q.; Xu, J.L.; Jiang, Z.L. Characterizing the May 2015 Karayaylak Glacier surge in the eastern Pamir Plateau using remote sensing. J. Glaciol. 2016, 62, 944-953. [CrossRef]

48. Chen, H.J.; Yang, J.P.; Tan, C.P. Responsivity of glacier to climate change in China. J. Glaciol. Geocryol. 2017, 39, 16-23.

49. Liang, Y.F.; Pei, X.J.; Cui, S.H.; Zhu, L.; Gao, H.H.; Dong, Y. Study on Geological Disaster Chain Effect of Huangdongzi Gully Induced by Wenchuan Earthquake and Breaking Measures. J. Catastrophology 2018, 33, 201-209.

50. Frattini, P.; Riva, F.; Crosta, G.; Fusl, N. Rock-avalanche geomorphological and hydrological impact on an alpine watershed. Geomorphology 2016, 262, 47-60. [CrossRef]

51. Immerzeel, W.; Van, B.L.; Bierkens, M. Climate change will affect the Asian water towers. Science 2010, 328, 1382-1385. [CrossRef]

52. Schaub, Y.; Huggel, C.; Cochachin, A. Ice-avalanche scenario elaboration and uncertainty propagation in numerical simulation of rock-ice-avalanche-induced impact waves at Mount Hualcand Lake 513, Peru. Landslides 2016, 13, 1445-1459. [CrossRef]

53. Nian, T.K.; Wu, H.; Chen, G.Q.; Zheng, D.F.; Zhang, Y.J.; Li, D.Y. Research progress on stability evaluation method and disaster chain effect of landslide dam. Chin. J. Rock Mech. Eng. 2018, 37, 1796-1812.

54. Yang, K.; Liu, Q. Supraglacial drainage system: A review. J. Glaciol. Geocryol. 2016, 38, 1666-1678.

55. Shroder, J.; Haeberli, W.; Whiteman, C. Snow and Ice-Related Hazards, Risks and Disasters; Elsevier: Amsterdam, The Netherlands, 2015; pp. 607-646.

56. Liu, C.Z. Preliminary findings on Dazhai landslide-debris flow disaster in Guizhou Province of June 28, 2010. J. Eng. Geol. 2010, 18, 623-630.

57. Ash, M.; Brennan, P.; Keylock, C.; Vriend, N.; McElwaine, J.; Sovilla, B. Two-dimensional radar imaging of flowing avalanches. Cold Reg. Sci. Technol. 2014, 102, 41-51. [CrossRef]

58. Qi, X.; Yu, B.; Zhu, Y. Experimental study on the clastic deposition forming debris flow. J. Jilin Univ. Earth Sci. Ed. 2014, 44, 1950-1959.

59. Wang, G.F.; Zhang, T.B.; Zhang, J.P.; Wu, H.; Yang, Q.L.; Ge, X.Y. Comparative Study of Glaciers Information Extraction Method Based on Remote Sensing Image. Geospat. Inf. 2010, 8, 43-46.

60. Wang, Y.; Lin, Q.G.; Shi, P.J. Spatial pattern and influencing factors of landslide casualty events. J. Geogr. Sci. 2018, 28, 259-374. [CrossRef]

(C) 2019 by the authors. Licensee MDPI, Basel, Switzerland. This article is an open access article distributed under the terms and conditions of the Creative Commons Attribution (CC BY) license (http://creativecommons.org/licenses/by/4.0/). 